\title{
Recent Advances in Strawberry Plug Transplant Technology
}

\author{
Edward F. Durner, ${ }^{1}$ E. Barclay Poling, ${ }^{2}$ and John L. Maas ${ }^{3}$
}

\begin{abstract}
Additional index words. Fragaria, soilborne disease, fumigant, pesticide, conditioned, mechanical planting, greenhouse forcing, plasticulture

Summary. Plugs are rapidly replacing fresh-dug bare-root and cold-stored frigo plants as transplants for strawberry (Fragaria $\times$ ananassa) production worldwide. Plugs have many advantages over these other types of propagules. They are grown in controlled environments (greenhouses, tunnels) in less time than field produced bare-root transplants, and are not exposed to soilborne pathogens. Plugs afford greater grower control of transplanting dates, provide mechanical transplanting opportunities and allow improved water management for transplant establishment relative to fresh bare-root plants. New uses for plugs have been identified in recent years; for example, photoperiod and temperature conditioned plugs flower and fruit earlier than traditional transplants and plugs have been used for programmed greenhouse production. Tray plants have superior cold storage characteristics relative to bareroot, waiting-bed transplants. Both fresh and frozen plugs are used in a number of indoor and outdoor growing conditions and cultural systems.
\end{abstract}

S trawberry plugs are fast replacing traditional bare-root transplants in many parts of the world as growers recognize that container-grown plant material usually provides a better opportunity to control critical production factors that influence plant health, rate of transplant establishment, early yield, total yield, and fruit size and/or grade characteristics. Plug production of bedding plants, vegetable transplants, pot crops, cut flowers, tissue-culture material, and trees has become a worldwide business. The number of plugs used in the U.S. and Canada is estimated to exceed 25 billion (Styer and Koranski, 1997). In Europe almost all greenhouse vegetables and cut flowers are plug propagated. In 1998, about 1 million large plug plants, also known as tray plants, were propagated in central Europe for glasshouse strawberries (F. Lieten, personal communication). The commercial production of tray plants is expected to increase in the United Kingdom over the next few years (Wilson, 1997). In the mid-Atlantic region of the United States, plug plants are recommended for late August (New Jersey) and early September (Virginia) transplanting in the annual plasticulture system (Pritts and Handley, 1998). Despite higher costs for plugs compared to fresh-dug bare-root plants, plug use increased in North Carolina from less than 1 million plugs in 1992 to an estimated 8 million plugs in 1998 (E.B. Poling, personal observation).

\footnotetext{
${ }^{1}$ Associate research professor, Rutgers University, Dept. of Plant Biology and Pathology, 59 Dudley Road, New Brunswick, NJ 089018520 .

${ }^{2}$ Professor, Dept. of Horticultural Science, North Carolina State University, Raleigh, NC 27695.

${ }^{3}$ Plant pathologist, USDA-ARS, Fruit Laboratory, B-010A, BARC-W, United States Dept. of Agriculture, Beltsville, MD 20705.
} 
A 1998 symposium, "Recent Advances in Strawberry Plug Transplant Technology" held at the XXV International Horticultural Congress in Brussels, Belgium, brought global attention to this newer method of strawberry propagation, and encouraged more research directed towards improving the practical application of this technology.

\section{Advantages of plug production technology}

Reduction in Pesticide ReQuireMENTS AND SOILBORNE DISEASES. StraWberry plug plants are grown from unrooted runners called tips. The tips are directly rooted into specially designed trays that usually contain a peatbased media, although direct rooting into rockwool propagation blocks is also possible (Poling and Parker, 1990). In a peat-based root media or rockwool, there is little likelihood of plugs becoming infected with verticillium wilt ( $\mathrm{Ver}$ ticillium spp.) and/or phytophthora root rot (Phytophthora spp.), unless the water supply is contaminated. The primary site of infection for phytophthora is in the meristematic region behind the root cap (Milholland and Daykin, 1993). Stem tissues such as stolons are not avenues of infection. Therefore, runner tips are ideal propagules for avoiding transmission of these root invading diseases. Chemical methods of control for these diseases have only limited effect once symptoms of the disease are observed (Wilson, 1997).

In the U.S., methyl bromide plus chloropicrin (MBC) is the preplant soil fumigant of choice used by nurseries for the control of soilborne diseases, nematodes and weeds. Other chemical alternatives to MBCinclude dichloropropene $85 \%$ + chloropicrin (Telone C; Dow AgroSciences, Indianapolis) and metamsodium (Vapam; AMVAC Chemical Corp., Los Angeles). As governments around the world take action to reduce and soon eliminate methyl bromide soil fumigation, there likely will be greater scientific and industry interest in systems for producing runner tips and strawberry plugs that are not dependent on a soil propagation phase.

Plug transplants are produced in no more than 5 weeks (Pritts and Handley, 1998), and in warmer growing regions (e.g., North Carolina, Florida, Egypt) the process of propagating a strawberry plug that is pullable from the plug tray for transplanting can be as little as 3.5 weeks. This short cycle makes it less likely that plugs will have as many problems with insect-vectored diseases as fresh-dug transplants that are exposed to field conditions for about 4 months from spring planting until late summer/fall harvest. Significant damage from the spread of viruses and phytoplasmas can occur during this extended period of field exposure. Additional benefits of producing a strawberry transplant in 4 weeks as opposed to 4 months may include more selective uses of pesticides, reduced worker exposure to pesticides, and lower pesticide residues in strawberry transplants. Sanitary, pest-free plant material is particularly essential to greenhouse strawberry producers as no registered pesticides are available in the U.S. for greenhouse production.

Ease of transplanting. Transplanting highly perishable fresh-dug plants is labor intensive, requiring up to 30 laborers/ha (12 laborers/acre). However, plugs can be mechanically transplanted, requiring a crew of only 5 workers to transplant about $0.6 \mathrm{ha} \cdot \mathrm{d}^{-1}$ (1.5 acres/d) (17,400 plugs) using a two-row plug transplanter. For a typical pick-your-own strawberry farm in North Carolina of only 1.2 ha ( 3 acres), the entire transplanting operation can be completed in $2 \mathrm{~d}$. A mechanical transplanter can consistently plant each plug so that the midpoint of the crown is level with the soil surface. With fresh-dug plants, inexperienced planting crews frequently fail to set the plants at the correct depth resulting in poor plant performance or even death.

Reduced water requirement. With fresh-dug plants, overhead irrigation must begin within $\mathrm{l} h$ of planting. These plants then require an intensive daily overhead-sprinkling schedule(from morning until late afternoon) for 1 to 2 weeks, depending on weather. Under hot, sunny conditions, it is beneficial to irrigate plugs for a few hours the day of transplanting. After the first day, plugs require very little, if any, overhead sprinkling. Water can be furnished to the plugs through the drip irrigation system following transplanting. This is a major benefit to the part-time grower who does not have time to oversee the daily overhead-sprinkling program needed for fresh-dug plants. It is also an important disease management strategy to minimize the use of any overhead irrigation after transplanting.

IMPROVED PLANT SURVIVAL. Nearly $100 \%$ of plug transplants survive trans- planting. With fresh-dug plants it is necessary to replace a significant number of weak or dead plants that do not survive the transplanting process. Plugs keep more root hairs, that quickly absorb water and nutrients. This active root system allows more uniform and faster plant growth after transplanting. Because of this faster initial growth, plug transplanting dates can be delayed (Pritts and Handley, 1998) by up to $5 \mathrm{~d}$ after the optimum planting date for fresh-dug plants (E.B. Poling, unpublished data).

\section{Industry uses of plug plants}

U.S. PLASTICULTURE PRODUCTION.

To achieve full production, timely planting is one of the most critical aspects of growing strawberries in the plasticulture system (Poling, 1993). In the eastern U.S., fresh plugs are field transplanted in middle to late summer, or fall, depending on the production area. For the mid-Atlantic region, growers transplant plugs in middle to late August or early September to achieve full crops the following spring. By obtaining 'Chandler' runner tips for plug propagation in mid-to-late July, strawberry growers in this region can be assured of having plants ready for field transplanting as early as mid-August for the plasticulture system. Fresh-dug bare-root transplants are not an option for growers in the mid-Atlantic region as northern U.S. and Canadian nurseries do not dig until after mid-September.

Further south, in North Carolina, growers can transplant either fresh bareroot transplants or fresh plugs in September, or early October, depending on growing area. Fresh bare-root transplants and fresh plugs will produce comparable yields (Poling, 1994). In North Carolina, both fresh plugs and freshdug bare-root transplants have similar reproductive physiology, and will ripen about $10 \mathrm{~d}$ earlier than dormant-stored transplants that were planted in late August (Poling and Durner, 1986).

In Florida, virtually all of the 2,350 ha (5875 acres) of production (Bish et al., 1997a) is planted in bare-root transplants costing $\$ 0.07$ to $\$ 0.08$ each $[\$ 3,200$ to $\$ 3,700 /$ ha $(\$ 8,000$ to $\$ 9,250 /$ acre) ]. The larger strawberry growers in Florida generally have access to relatively inexpensive labor for transplanting the cheaper fresh bare-root transplants. With delivered plugs costing $\$ 0.14$, few growers in that state feel 
that spending another $\$ 3,200 / \mathrm{ha}$, or more, for plugs is justified. However, temperature (Bish et al., 1997a) and/or photoperiodically (Durner and Poling, 1998) conditioned plugs, that can have significantly higher early and total winter production in southwest-central Florida than bare-root transplants from the northern U.S., may warrant the higher establishment costs associated with plugs.

U.S. GREenHOUSE PROdUCTION. Artificial night chilling $\left[4.5{ }^{\circ} \mathrm{C}(40.1\right.$ ${ }^{\circ} \mathrm{F}$ ) from 1900 To $0800 \mathrm{HR}$ for 15 cycles $]$ enhanced fall and winter greenhouse productivity of plug plants derived form secondary and tertiary runner plants of 'Selva' (Hamann and Poling, 1997). Secondary plugs had higher early season fruiting compared to tertiary plugs.

Conditioned plug plants were successfully used for winter greenhouse production in New Jersey. In one experiment, (Durner, 1999), 2- to 3week-old 'Sweet Charlie' strawberry plug plants were conditioned [ 7 short days $(9$ h) without chilling $\left(21 / 21^{\circ} \mathrm{C}\left(69.8^{\circ} \mathrm{F}\right)\right.$ day/night)] followed by 7 short days ( 9 h) with chilling during the nyctoperiod [21 $/ 12{ }^{\circ} \mathrm{C}\left(69.8 / 53.6^{\circ} \mathrm{F}\right)$ day/night $]$ in September, then planted in a vertical hydroponic system for winter greenhouse production. Conditioned plugs produced significantly more fruit than did nonconditioned control plugs in January and February, but the difference was not significant in March and April. Productivity over 4.5 months was $4.8 \mathrm{~kg} \cdot \mathrm{m}^{-2}\left(1.0 \mathrm{lb} / \mathrm{ft}^{2}\right)$ for controls and $7.8 \mathrm{~kg} \cdot \mathrm{m}^{-2}\left(1.6 \mathrm{lb} / \mathrm{ft}^{2}\right)$ for conditioned plugs.

Takeda et al. (1997) investigated the use of aquaculture wastewater as a source of water and nutrients for hydroponically grown plug plants of 'Chandler'. Plants produced more than $600 \mathrm{~g}$ (1.3 lb) per plant from January through March and also effectively reduced phosphorus discharge from aquaculture wastewater.

European plasticulture and GREENHOUSE PRODUCTION. In central Europe, fresh 'Elsanta' plugs are propagated for transplanting into field plasticulture by late July or early August. These plants will produce a main crop the following late May and June, or can be forced for 2 weeks earlier fruiting in May by covering the crop with a high plastic tunnel. A portion of the maiden year plasticulture beds in the U.K. may be deep strawed for delayed fruiting after the main season when lower vol- umes of 'Elsanta' on the market can lead to significantly higher prices. Runner tips of 'Elsanta' can be readily obtained in midsummer from a variety of propagators in central Europe and the U.K., or from specialized runner tip growers in southern Portugal and Spain.

In the U.K., a limited number of commercial producers are also establishing field nurseries with 'Elsanta' plugs in late July and early August. The transplants are allowed to develop in the field until being lifted (dug) in December when there has been an accumulation of 500 to 600 h of temperatures below 6 ${ }^{\circ} \mathrm{C}\left(42.8^{\circ} \mathrm{F}\right)$ and/or before a hard frost. Transplants are then either planted in the glasshouse, or placed in cold storage at $-1.5^{\circ} \mathrm{C}\left(29.3^{\circ} \mathrm{F}\right)$. Plants are graded as waiting-bed plants $[17 \mathrm{~mm}(0.7$ inches) crown diameter], or A+ plants [ 15 to $17 \mathrm{~mm}$ ( 0.6 to 0.7 inches) crown diameter]. Nongraded field-conditioned plugs are also dug and stored.

In recent years there has been a move to commercial strawberry tray plant production in parts of central Europe where conventional bare-root waiting-bed and A+ plants for glasshouse strawberries have now been replaced by tray plants (F. Lieten, personal communication). Tray plants have the potential to produce 'Elsanta' fruit of very high cosmetic appearance (Johnson, 1995) and often produce higher yields and larger fruit than a similar size frozen $\mathrm{A}+$ bare-root plant, partially offsetting their extra cost (Wilson, 1997).

Waiting-bed plants have been used for winter production in Spain (LopezGalara et al., 1997). Productivity of four cultivars was influenced by the number of crowns (one to five) each plant had at planting. 'Oso Grande' was most productive with two crowns per plant, 'Vilanova' and 'Pajaro' were most productive with three crowns per plant, and 'Chandler' was most productive with four or five crowns per plant.

Winter production in both high and low tunnels in Turkey has been reported (Kaska et al., 1997; Ozdemir and Kaska, 1997; Turemis et al., 1997). In one study, plugs planted in August produce fruit by early November while frigo plants set at the same time did not produce fruit until the following February (Ozdemir and Kaska, 1997). In another study, both types of plants set in the field in July did not fruit until February (Turemis et al., 1997). Later fruit production (February onward) was associated with frost injury to flowers in
November and December (Kaska et al., 1997).

Plug plant production. Plug propagation is divided into several stages beginning with the production of unrooted plantlets on the tips of runners, and ending with a fully rooted plug that is ready for shipping, transplanting, special conditioning or holding in cold storage.

Runner tip Production. The first propagation step is to generate a supply offresh runner plantlets commonly called tips. A common approach in Canada is to grow the tips from California-nursery-registered stock plants (Strand, 1993) that are transplanted in double rows $[43,000$ plants /ha (17,200 plants / acre)] on fumigated, raised beds that are covered with black plastic mulch. With this system in southern Ontario, the first runner tips are harvested in just 8 to 10 weeks after planting in early June. Fresh tips of the popular eastern cultivar 'Chandler' are commercially harvested from the end of July through the first week of September. Tips are harvested at frequent intervals (two to three times per week, depending on temperatures) to provide greater plant-size uniformity. Potentially, a higher yield of stolons and daughter plantlets than 10:1 could be achieved if the tip nursery was not harvested so frequently. But, the market in the mid-Atlantic region and North Carolina dictates that the runner tips are harvested frequently to keep the plantlets within a relatively narrow size range. Recommended specifications for runner tip propagators are as follows.

Stock plant material. Use only certified stock that is free of disease causing virus, fungi and bacteria.

Number of intact leaves. Two trifoliate leaves are needed. The leaves should not be trimmed, or cut off (Lieten, 1994). The petioles must not be injured.

Height of oldest trifoliate. Nutrition, watering and cultural practices should be tailored to produce a plantlet that does not have the older trifoliate extending more than $10 \mathrm{~cm}$ (3.9 inches) in height from the base of the small crown.

Grading by leaf height. There is an acceptable range in plantlet size with the oldest trifoliate measuring a minimum of about $6.5 \mathrm{~cm}$ (2.6 inches) up to 10 $\mathrm{cm}$ (3.9 inches). Tips that are larger or smaller should not be harvested for plugs.

Crown diameter. 20 to $50 \mathrm{~mm}(0.8$ 
Table 1. Definitions of terms specific to the commercial strawberry industry.

\begin{tabular}{|c|c|}
\hline Term & Definition \\
\hline \multicolumn{2}{|r|}{ 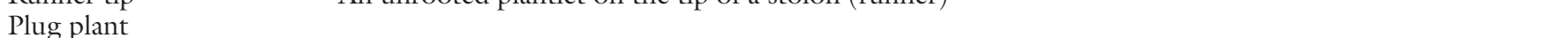 } \\
\hline Tip-raised potted plant & $\begin{array}{l}\text { Small containerized plants produced from runner tips, generally grown for } 3-5 \text { weeks in } 50 \text {-cell plastic trays } \\
\text { with cell depths of } 5-6 \mathrm{~cm} \text { ( } 1.9-2.4 \text { inches }) \text {, average crown diameter } 8-11 \mathrm{~mm}(0.3-0.4 \text { inches }) \text {. }\end{array}$ \\
\hline Tray plants & Containerized plants produced from runner tips, typically grown over a 5-month period (late July- \\
\hline Waiting-bed plants & Fresh-dug nursery plants with a crown diameter of $17 \mathrm{~mm}(0.7$ inches $)$ or more. \\
\hline Fresh-dug bare-root plant & $\begin{array}{l}\text { A field nursery-grown strawberry plant that is dug and transplanted to the production field within several } \\
\text { days. }\end{array}$ \\
\hline Frigo plants & Dormant strawberry plants stored for several months at $-1.5^{\circ} \mathrm{C}\left(29.3^{\circ} \mathrm{F}\right)$. \\
\hline
\end{tabular}

to 1.9 inches) (more research needed).

Stolon attachment to crown. 1 to 1.5 $\mathrm{cm}(0.4$ to 0.6 inches $)$ section is ideal for anchoring the tip in peat-based soil or rockwool media. Some research indicates that stolon diameter of $4 \mathrm{~mm}$ $(0.15$ inches $)$ is preferable to $2 \mathrm{~mm}$ (0.08 inches) for earliest floral initiation.

Root system. Plantlets are too small for harvest and plugging if there are not several peg roots, or root nodules formed (rooting success will be limited without peg roots). The plantlet is not as desirable for rooting if the peg roots are dark (should be whitish) or if roots more than $1 \mathrm{~cm}$ (0.4 inches) (Pritts and Handley, 1998) have been expressed. There should be no soil particles attached to the plantlet.

In Belgium and the Netherlands the preferred system for producing runner tips for tray plant production is to plant frigo stock plants in plastic peat bags that are placed on top of a white polyethylene film-covered-bed (to prevent tips from contacting soil), and the aisle area is covered in wheat straw. The stolons spread horizontally on the wheat straw, and are harvested as tips in midJuly. Suspended systems for growing tips generally have been abandoned in central Europe because of shading problems that causes a premature transition from a vegetative to a floral meristem. Additionally, the upward orientation of the 1 to $1.5 \mathrm{~cm}$ ( 0.4 to 0.6 inches) stolon section attached to the base of the young plantlet makes it impossible to use this stub for anchorage of the runner tip in the cell module.

Rooting. Most commonly a greenhouse or plastic tunnel is used for rooting runner tips under mist. An enclosed structure is needed to prevent damage from high wind and/or heavy rain. Shadehouses can be used, but these structures are usually ineffective for wind and rain control. In addition, light levels under shade structures will be insufficient after the first week of rooting. Strawberry plugs also can be produced inexpensively outdoors (Lieten, 1994). The plug trays are placed on top of woven polypropylene ground covers and are then covered on top with a thin white polyethylene film. The white plastic film reduces radiant heat, and provides a humid environment under the tarp to prevent wilting of the perishable runner tip. Difficulties with this method often relate to having too much covering during the first 2 weeks of rooting and new leaf development. When the weather is cloudy and rainy for several days, plugs will stretch because light levels are too low. It is also more difficult to regulate moisture underneath plastic tarps, and in cool, overcast periods; grey mold (Botrytiscinerea) will readily spread from weak plant tissues and fresh plant debris to healthy leaves under such conditions.

Little published work exists on the effects of tray construction (styrofoam, polyethylene, polypropylene), cell sizes (small, medium, large), and cell configuration (plugs may be round, square, hexagonal, octagonal, or star-shapes) on strawberry plug rooting amount, root quality, and plug pullabililty for transplanting. There is some literature that addresses questions related to the interaction of the medium with strawberry plug size and geometry (Bish et al., 1997b). The root dry mass and root branching of 'Sweet Charlie' plug transplants fertigated on a capillary mat for 4 week was highest in a $150-\mathrm{cm}^{3}(9.1$ inch $\left.^{3}\right)$ container volume $[6.5-\mathrm{cm}(2.6$ inch) cell depth] and 0.31 to $0.43 \mathrm{~cm}$ (0.12 to 0.17 inches) particle size vermiculite. In North Carolina, the general commercial practice is to use a nonreus- able, round, straight-sided, 50 -cell, polyethylene tray $[5.7 \times 27 \times 53 \mathrm{~cm}(2.2 \times$ $10.6 \times 20.9$ inches $)]$ costing about $\$ 0.40$ each. Plug trays are usually filled by hand with a commercial plug mix that contain peat, vermiculite and some amount of composted pine bark, processed bark ash and washed granite sand. When placed in a $5.7-\mathrm{cm}$ (2.2-inch) deep tray, it is common to have about $6 \%$ air space and $75 \%$ water content. About $5 \mathrm{~L}$ (1.3 gal) of mix is needed per 50 -cell tray (about $\$ 0.50$ per tray). The plug mix must be moistened before sticking tips and the trays should not be nested directly on top of each other to avoid compaction.

Well-produced runner tips require no additional preparation before rooting, and can be taken directly from the box without additional size grading and trimming of stolons. An approximate 1.5 to $2.0 \mathrm{~cm}$ (0.06 to 0.08 inches) runner stub serves to anchor the plantlet until new roots develop [within $48 \mathrm{~h}$ new roots of 3 to $4 \mathrm{~cm}(0.12$ to 0.16 inches) in length usually penetrate the plug mix]. An intermittent-mist water spray over the leafy tips is the most effective way to root strawberry plugs. The initial rooting stage under mist requires about 7 to $10 \mathrm{~d}$. In the first few days under warm sunny conditions it is advisable to mist more frequently $(10 \mathrm{~s}$ of mist every $5 \mathrm{~min}$ ). After the first few days it is usually satisfactory to mist for 30 s every 12 min (Bish et al., 1997a). The goal is to gradually decrease the misting period as new roots develop by lessening the "on" period and increasing the "off" periods, or by leaving the misting intervals the same but gradually decreasing the time for which the mist is in operation each day. Misting is usually terminated by day 10 , but under some circumstances it may require $12 \mathrm{~d}$. For the next week the plugs are watered 
regularly, and by the end of the third week the plug trays can be moved into full sun for weeks 4 and 5 (if needed). The trays may be placed on top of woven polypropylene ground covers or a nursery gravel pad for the final week or two of outdoor hardening. Byweek 4 or 5 the plug is ready to be pulled from the tray for transplanting without the media falling off the roots.

Conditioning. Before transplanting, the strawberry plug can be manipulated, or conditioned, for glasshouse forcing in winter (Durner, 1999) or for earlier winter production in regions with moderate temperatures (e.g., Florida, Southern California, Israel, and Egypt) (Durner and Poling, 1998). Short day (SD) low-chill cultivars are good candidates for conditioning programs in areas with moderate winter temperature conditions and photoperiods ofless than $14 \mathrm{~h}$ (Larson, 1994). An extensive amount of research was done in the mid-to-late 1980s to identify cultivar specific photoperiodic and chilling requirements in potted transplants of 'Douglas', 'Pajaro', 'Chandler' and 'Tufts' (Durner et al., 1986). More recent investigations have focused on preconditioning plugs of commercially popular SD-low chill cultivars ('Sweet Charlie', 'Camarosa') for an earlier winter ripening period (when prices are normally higher).

Over 10 years ago, Durner et al. (1986) demonstrated that the SD lowchill cultivar 'Douglas' grown in 10.5$\mathrm{cm}$ (4.1-inch) plastic pots in a North Carolina nursery responded primarily to photoperiod for enhanced early fruiting in Florida winter plantings. While the transition from a vegetative to floral meristem in 'Douglas' is rapid (about $14 \mathrm{SD}$ photoinductive cycles at $9 \mathrm{~h}$ daylength), an additional 14 cycles were needed to optimize flower buds and/or increase floral initiation. The number of SD photoinductive cycles for optimum early yields could be reduced with night chilling $\left[4.4^{\circ} \mathrm{C}\left(40^{\circ} \mathrm{F}\right)\right]$. The photoperiod response varies with cultivar and chilling. In 'Pajaro' and 'Douglas', chilling accentuated the photoperiod effect and enhanced early yields. In 'Chandler', low levels of chilling $(<125 \mathrm{~h})$ reduced early yield while higher amounts (>125 h) enhanced early yield.

The conclusion that the initiation of flower buds is controlled primarily by photoperiod and to a much lesser degree by temperature was further supported by more recent investigations.
Three-week-old vegetative 'Sweet Charlie' and 'Camarosa' plugs were exposed to 8 -h short days for 1,2 , or 3 weeks at either 10 or $16^{\circ} \mathrm{C}(50$ or 60.8 $\left.{ }^{\circ} \mathrm{F}\right)$ night temperature $\left[22^{\circ} \mathrm{C}\left(71.6^{\circ} \mathrm{F}\right)\right.$ day]. Short day conditioning of plugs in weeks 4,5 , and 6 before transplanting in Florida (24 Oct.) significantly enhanced early (December) yield in both cultivars (Durner and Poling, 1998).

In another investigation of conditioning, 3-week-old 'Sweet Charlie' plugs conditioned for 2 weeks at 25/15 ${ }^{\circ} \mathrm{C}\left(77 / 59^{\circ} \mathrm{F}\right)$ day/night temperatures flowered earlier and had higher November and total yield compared to plugs conditioned at $35 / 25^{\circ} \mathrm{C}\left(95 / 77^{\circ} \mathrm{F}\right)$ (Bish et al., 1997a). However, the photoperiod effect was not investigated. The optimal daylength for floral induction in SD cultivars is generally between 8 and 12 h, but the role of photoperiod is more critical at temperatures above 15 ${ }^{\circ} \mathrm{C}$ (Larson, 1994). It is possible that the natural photoperiod in Dover, Fla. during this temperature conditioning (from 19 Sept. to 3 Oct.) was satisfactory (short enough) for floral induction at $15 / 15^{\circ} \mathrm{C}$, but not for the warmer $35 /$ $25^{\circ} \mathrm{C}$ day/ night temperature condition. Clearly, in plug conditioning investigations, photoperiod and temperature both must be investigated if the goal is to optimize conditioning parameters to induce precocity and enhance yield.

The general fruitfulness of SD lowchill strawberry plugs and potted plants can be managed by controlling the length of time plants are grown under short days, and that dark period chilling [4.4 to $10{ }^{\circ} \mathrm{C}\left(40\right.$ to $\left.50{ }^{\circ} \mathrm{F}\right)$ ] during floral induction can enhance total yield for certain cultivars (Durner et al., 1986). However, more research is needed to understand the critical photoperiod requirements of newer low chill or nochill SD cultivars (i.e., 'Sweet Charlie') and how warmer temperature treatments (i.e., $35 / 25^{\circ} \mathrm{C}$ day/night) may influence the number of SD cycles needed for floral induction.

Storage. Runner tips are generally cut and graded in the field and then moved quickly to the cooler $\left[0\right.$ to $1^{\circ} \mathrm{C}$ (32 to $\left.33.8^{\circ} \mathrm{F}\right), 95 \%$ relative humidity]. Tips are frequently collected underwarm to hot conditions in southern Ontario (July, early August), and it is essential to remove them from the field as quickly as possible, preferably in $45 \mathrm{~min}$ or less. The tips should be cooled to $0{ }^{\circ} \mathrm{C}$. A good cold chain from the runner tip producer to the plug grower is essential for best rooting success. The temperature of tips should not be allowed to rise above 2 to $3{ }^{\circ} \mathrm{C}\left(35.6\right.$ to $\left.37.4{ }^{\circ} \mathrm{F}\right)$ in transit. Well-handled runner tips have a safe storage life of up to 1 week, but every reasonable effort should be made to root the runner tips as soon after harvest as possible. Tips may be safely held in a cooler at the plugging location for a few days at $3{ }^{\circ} \mathrm{C}$.

Tray plants have cold storage properties that are better than bare-root waiting-bed plants(Lieten, 1994). They provide more rapid and even establishment under hot midsummer conditions under glass than similar size bare-root A+ plants (Wilson, 1997). When dormant, the plants can be removed from the trays and placed in cold storage at $1.5{ }^{\circ} \mathrm{C}\left(29.3^{\circ} \mathrm{F}\right)$ for up to 8 months.

Shipping. Properly grown tips are compact in size and 1,000 tips with box and liner will weigh about $5 \mathrm{~kg}$ (11 lb). As a result, runner tips are economical to ship by air freight. The greatest expense for growing runner tips is for hand labor to collect and pack the tips. Transportation costs for shipping tips are very low relative to shipping a finished plug, or fresh-dug bare-root transplant. A box containing 1,000 compactly grown strawberry runner tips shipped from Ecuador to Miami, for example, will have freight charges for air shipment that average less than $\$ 0.005$ per tip. Local shipment of finished plugs from the plugging greenhouse to area growers is easily accomplished with flatbed trucks. Specially fitted trailers with plugtray carrying racks are needed to transport large numbers of plugs greater distances. A common carrier tractor trailer in the U.S. equipped with racks can hold about 1,200 50-cell trays $(60,000$ plugs $)$ at a cost per plug that is roughly three times higher than shipping costs for a runner tip.

\section{Summary}

Container-grown strawberry plug plants offer an important alternative to conventional field-grown strawberry transplants. Strawberry plugs are grown in controlled environments (greenhouse, tunnels) in less time than field produced bare-root transplants, and are not exposed to soilborne pathogens. Plugs afford greater grower control of transplanting dates, provide mechanical transplanting opportunities, and allow improved water management for transplant establishment relative to fresh bare- 
root plants. New uses for plugs have been identified in recent years, including earlier flowering and fruiting with conditioned plugs, and in glasshouse production. In time, labor issues and prevailing environmental concerns throughout the world may increase interest in strawberry plugs, but higher prevailing costs for this propagation method is limiting current plug usage to specialized niche applications. The scientific community has an opportunity to improve industry adoption of plug plants by developing more cost-effective methods for producing large volumes of disease-free runner tips, and improve the evenness and growth of plug plantsin the tray and thereby achieve more uniform growth and fruiting after transplanting. In the future, scientists may learn to inoculate strawberry plugs with various performance-enhancing agents and possibly reduce plug size for savings in media, plastic trays and greenhouse space. Exposing plugs to different natural environments for meristem conditioning effects can advance flowering and fruiting, but plug trays are bulky and expensive to move. Researchers need to identify less expensive means to condition strawberry plugs, preferably on one site. Finally, well-coordinated efforts between horticulturists, engineers and industry, could lead to useful applications of robotics in strawberry runner-tip harvest, plug rooting, transplanting and conditioning.

\section{Literature cited}

Bish, E.B., D.J. Cantliffe, G.J. Hochmuth, and C.K. Chandler. 1997a. Development of containerized strawberry transplants for Florida's winter production system. Acta Hort. 439:461-468.

Bish, E.B., D.J. Cantliffe, and C.K. Chandler. 1997b. Container volume and media particle size alter growth of strawberry transplants. Proc. Fla. State Hort. Soc. 110:258-261.

Durner, E.F. 1999. Winter greenhouse strawberry production using conditioned plug plants. HortScience 34:615-616.

Durner, E.F. and E.B. Poling. 1998. Phytotron research investigations with conditioned 'Sweet Charlie' and 'Camarosa' plugs. Acta Hort. 513:403-408.

Durner, E.F., E.B. Poling, and E.E. Albregts. 1986. Early season yield responses of selected strawberry cultivars to photoperiod and chilling in a Florida winter production system. J. Amer. Soc. Hort. Sci. 112:53-56.

Hamann, K.K. and E.B. Poling. 1997. The influence of runner order, night temperature and chilling cycles on the earliness of 'Selva' plug plant fruit production. Acta Hort. 439:597-604.

Johnson, D. 1995. Under cover action on strawberries. The Grower (13 July 1995):22.

Kaska, N., N. Turemis, S. Kafkas, and N. Comlekcioglu. 1997. The performance of some strawberry cultivars grown under high tunnels in the climatic condition of Adana(Turkey). Acta Hort. 439:297-300.

Larson, K.D. 1994. Strawberry, p. 271297. In: B. Schaffer and P.C. Anderson (eds.). Handbook of environmental physiology of fruit crops. vol. 1. Temperate crops. CRC Press, Boca Raton, Fla.

Lieten, F. 1994. Short cut strawberry propagation. The Grower (19 Mar. 1994):35.

Lopez-Galarza, S., J.V. Maroto, A. San Bautista, and J. Alagarda. 1997. Performance of waiting-bed strawberry plants with different number of crowns in winter plantings. Acta Hort. 439:439-443.

Milholland, R.D. and M.E. Daykin. 1993. Colonization of roots of strawberry cultivars with different levels of susceptibility to Phytophthora fragariae. Phytopathology 83:538-542.
Ozdemir, E. and N. Kaska. 1997. The production of early strawberries in new and re-used growing media in sacks under a walk-in tunnel. Acta Hort. 439:501507.

Poling, E.B. and E.F. Durner. 1986. Annual strawberry hill cultural system in southeastern North Carolina. HortScience 21:240-242.

Poling, E.B. and K. Parker. 1990. Plug production of strawberry transplants. Adv. Strawberry Prod. 9:37-39.

Poling, E.B. 1993. Strawberry plasticulture in North Carolina: II. Preplant, planting, and postplant considerations for growing 'Chandler' strawberry on black plastic mulch. HortTechnology 3(4):383-393.

Poling, E.B. 1994. A two-year field comparison of strawberry fresh-dug and plugtransplants on plastic mulch. Acta Hort. 348:276.

Pritts, M.P. and D. Handley (eds.). 1998. Strawberry production guide for the Northeast, Midwest and eastern Canada. Cornell Univ. Coop. Ext. NRAE-88.

Strand, L. 1993. Integrated pest management. Univ. Calif., Davis, Publ. 3351.

Styer, R.C. and D.S. Koranski. 1997. Plug and transplant production: A grower's guide. Ball Publ., Batavia, Ill.

Takeda, F., P.R. Adler, and D.M. Glenn. 1997. Strawberry production linked to aquaculture wastewater treatment. Acta Hort. 439:673-677.

Turemis, N., N. Kaska, S. Kafkas, and N. Comlekcioglu. 1997. Comparison of yield and quality of strawberry cultivars using frigo plants and fresh runners rooted in pots (1993-94 growing season). Acta Hort. 439:537-542.

Wilson, D. 1997. Strawberries under protection. Grower Guide No. 6. 2nd Ser. Grower Books, Nexus Media Limited, Kent, U.K. 